\title{
Self-Efficacy And Motivation On Entrepreneurship Interest In Politeknik Media Kreatif College
}

\author{
Efry Kurnia ${ }^{1}$ and Roza Maya Sari ${ }^{2}$ \\ \{ efrikurnia@umsu.ac.id ${ }^{1}$ \} \\ ${ }^{1}$ Univeristy of Muhammadiyah Sumatera Utara, Jalan Kapten Mukhtar Basri No. 3 Medan, Indonesia \\ ${ }^{2}$ Faculty of Economic, Prima University, Medan, Indonesia
}

\begin{abstract}
This study aims to determine the effect of self-confidence and motivation on entrepreneurship directly attractive. This research was conducted at the Media Kreatif of Medan State Politeknik College North Sumatra which aimed to see and know selfefficacy, and motivation towards the interests of Polytechnic Institute entrepreneurial students. The quantitative descriptive study of this research with the nature of the research is an explanation. The population includes students in the creative State Polytechnic Media field, amounting to 200 students with a sample of 133 people. Research data is collected through questionnaires that have been distributed to students. Study documentation is done by collecting and studying supporting documents, information, and data. The data analysis technique uses regression analysis. The results showed that trust in the interests of entrepreneurship had a positive and significant value, as well as motivation.
\end{abstract}

Keywords: Self-Efficacy, motivation, entrepreneurship interest.

\section{Introduction}

At present, Indonesia is a country that has a population that continues to increase every year, in 2018, the population is around 266,927,712 and Indonesia ranks 4th with the population in the world according to estimates by the Department of Economic and Social Affairs. From the market side, a sizeable population is an advantage in industrial development that is able to absorb labor and resources that can be developed properly. In fact, this has increased industrial progress expressed by the head of BPS, Suhariyanto in a limited meeting at the Office of the President "while in the manufacturing sector, there was an increase of 0.39 percent. namely, other service sectors, the following manufacturing industry sectors. However, the industrial sector has not been able to reduce unemployment, where employment opportunities are limited and not proportionally proportional to the number of population growth and an increase in the number of labor strikes. good to undergraduate level.

This gap is a major problem in the world of work. Where almost every graduate aims to find work instead of creating new jobs (entrepreneurship). Being an entrepreneur is one of the right alternatives at least with entrepreneurship means providing a job for yourself, no need to depend on others. In Indonesia, almost all tertiary institutions are oriented to make their students as potential entrepreneurs, and some universities include Entrepreneurship education courses as compulsory subjects. This is so that college graduates are able to create jobs for yourself.

But in reality, many students are less interested in starting a business. By reason of lack of confidence to start entrepreneurship and lack of motivation from internal and external environments. The growth of entrepreneurial interest cannot be immediately carried out without education and training that can move the entrepreneurial spirit. With the presence of 
entrepreneurship courses with a number of supporting subjects, it is expected to encourage the interest of students to be more confident and motivated to start a new business or entrepreneurship. This is explained from Previous researchers have proven that entrepreneurial intent is the primary predictor of a future entrepreneur (Franco et al., 2010).

Creative Media State Polytechnic known as Polimedia is one of the university-based technologies. Where students are required to be able to learn the technology provided when the technology affects all aspects including entrepreneurship. During college, students have time to learn the various knowledge needed. Students are required to develop and utilize science and technology to be able to open employment. opportunities. The knowledge and skills they encourage their interest in the game after work by creating self-confidence and motivating them to become skilled resources. Based on the background as described above, the problems in this research can be identified as follows; Still, lack a sense of self-efficacy student polytechnic to start entrepreneurship of the motivation of entrepreneurship in students the desire to polytechnic, and low-interest student entrepreneurship at a polytechnic.

\subsection{Entrepreneurship}

An entrepreneur is someone who can make things and process raw materials. (Schumpeters, 1965), entrepreneurs as modifiers and development for new economies that always launch new products and services along with other resources. (Suryana and Bayu, 2013), defines entrepreneurship as someone who has created a new business with bold risks and uncertainties aimed at seeking profit and business growth based on identifying opportunities and being able to utilize existing resources and provide capital to this opportunity. While according to (Segal, et., 2005) suggested two theories regarding encouragement to entrepreneurship, "push" theory and the "pull" theory. According to "push" theory, individuals are pushed to become entrepreneurs due to the encouragement of negative environment, for example, dissatisfaction at work, difficulty finding jobs, lack of inflexibility work hours or dissatisfaction salary. In contrast, "pull" theory stated that individuals interested in becoming entrepreneurs because they are looking for things related to the entrepreneur's own characteristics, such as independence or indeed because it believes entrepreneurship can provide prosperity.

From the definition above, it can be concluded that entrepreneurship is someone who is capable and has the creativity to manage natural resources or human resources and dare to face risks and uncertainties with confidence in their abilities.

\subsection{Entrepreneurship Interest}

According to Santoso (Agustina and Sularto, 2011), the entrepreneurial interests of psychological symptoms are focusing on and doing something about the entrepreneur with a feeling of happiness because it brings benefits to himself. Meanwhile, according to Katz and Gatner, it was explained that intense entrepreneurship or interest in entrepreneurship can be interpreted as information on the search process that can be used to achieve business establishment goals. (Budiati, et al., 2012).

While according to Mappiare (in (Adhitama, 2014) interest is a mental device consisting of a mixture of feelings, hopes, establishment, prejudice, fear or other tendencies that direct individuals to certain choices.

From then on, it can be concluded that the interest in entrepreneurship is the attraction, desire and willingness to work hard trying to fulfill their needs and run their business without fear of risk and always learn from failures experienced.

(Venesaar, et al., 2006) in a study entitled Student Attitudes and Intentions on Entrepreneurship at Tallinn University of Technology (2006) divided entrepreneurial interest 
into four categories, namely; not interested in becoming an entrepreneur; already interested, but haven't started yet; Already have and run a business, and have tried before, but failed.

While the interest in entrepreneurship based on time perspective is divided into four categories (Venesaar, et al., 2006), namely: interest in entrepreneurship in the period approaching / after graduation; interest in entrepreneurship in the next two years; Interest in entrepreneurship in the long term / in the future; haven't determined the time to start.

The indicator of measuring interest in entrepreneurship according to (Sumarwan, 2003) measures interest in work or interest in entrepreneurship can be done with 3 indicators as follows: The cognitive component is knowledge and perception obtained through experience with objects, attitudes, and information from various sources. Knowledge and perceptions that are usually in the form of trust and trust are trusts that is the existence of object attributes having various specific attitudes and behaviors; Affective components describe a person's feelings and emotions towards an object. A person's feelings and attitudes are a comprehensive evaluation of the object of attitude. The affective component here shows a direct and general assessment of an object. A person's feelings and emotions are primarily aimed at the object as a whole, not feelings and emotions towards the attributes possessed by an object. Feelings and emotions are depicted by expressions of two different traits to evaluate objects and the third is cognitive Components of Conative Components show actions or tendencies of a person's behavior towards an object. From this theory, the measurement of interest in this study is carried out with indicators namely cognitive-affective components, components, and cognitive components.

\subsection{Self-Efficacy}

According to (Ryan, 1970), self-perfection, or the way a person views his abilities and tendencies, plays a role in developing intention. Likewise, self-efficacy influences one's beliefs about whether certain goals can be achieved or not. Self-efficacy is a measure that can be studied and is useful to explain a voting process in entrepreneurial intentions and behavior in subsequent decisions (Bandura, 1994). To understand this process, first, need to define and describe self-efficacy as a construct. According to Lauster (Sudardjo and Purnamaningsih, 2003) trust is not innate but is derived from life experience, and can be taught and instilled through education, so special efforts can be made to build and enhance self-confidence.

(Ghufron, M and Risnawita, 2010) say trust can grow through things as follows: selfconcept, a person's self-confidence can grow with a concept that is self-acquired in sexual relations within a group. The results of interactions that occur 31 will produce self-concept; self-esteem, if someone has high self-esteem then it will affect their level of confidence; experience, experience can be a factor in the emergence and decline of one's self-confidence; and finally education, a person's level of education will affect his confidence, because when someone has a low education then it will make people depend on power and become someone who is smarter than him, while those who have higher education will have more levels of trust that people who have low education. Therefore, Entrepreneurial self-efficacy is students' judgments about their abilities to successfully create a new venture and play the roles and tasks of an entrepreneur (Chen,et al., 1998).

\subsection{Entrepreneurship Motivation}

Motivation is the willingness to do something about motives for motivation, motives are a need, desire, encouragement or implus (Buchari, 2007). (Mahesa and Rahardja, 2012) leads human motivation to do things to achieve certain goals. Motivation is encouragement from someone who encourages people to do something, including being a young entrepreneur 
(Sarosa, 2005). tells us that motivation in entrepreneurship including motivation is directed at achieving entrepreneurial goals, such as goals involve the introduction and exploitation of business opportunities (Baum, et., 2007).

According to (Buchari, 2007), Motivation is the willingness to do something about motives in motivation, motives are needs, desires, impulses or implus. While according to (Hrehová, 2013) Proper motivation is important for new business owners or future entrepreneurs to go into business.

According (Robicahud, et., 2001) Motivating factors can be either internal or external to the entrepreneur. According (Basrowi, 2014) factors that influence motivation: a) Need (need) someone to do activities (activities) because of factors both biological and psychological needs; b) expectations (expectations) A person is motivated because of expectations of success, namely self-satisfaction, success, and one's self-esteem increases and moves a person toward achieving goals; c) Interest. Flowers are the likes and desires of something without any telling or activities often carried out every day because of the activities that are liked. 2) Extrinsic Motivation Motivation is extrinsic from encouragement from outside individuals that causes individuals to participate in activities. Factors that influence extrinsic motivation (Basrowi, 2014); a) Family encouragement is a group consisting of two or more people who each have kinship consisting of a father, mother, grandfather, grandmother; b) Environmental Environment is the place where people live. The environment can affect someone, so they can be motivated to do something. In addition to the family environment also has a big role in motivating someone whose behavior changes; c) A person's gifts can be motivated because of the rewards so that people want to do something. And (Kuratko, et al., 1997) classified motivators into four categories: extrinsic rewards, independence/ autonomy, intrinsic rewards, and family security.

\section{Methodology}

Type of this research is the quantitative description. The research of quantitative as described (Sugiyono, 2015), quantitative research is the systematic scientific research sections and phenomena as well as correlation. The nature of research is explanatory research description, which is the research that intends to explain the position of the variable-variables are examined as well as the relationship between one variable with another variable. The population examined is students Creative Media State Polytechnic Medan 2017/2018 school year amounted to 200 students. Sample withdrawal technique in this study using simple random sampling. And a sample is obtained using the formula slovin with an error rate of $5 \%$ of the sample obtained at 133 students Creative Media Country Polimedia terrain. In this study data collected through a questionnaire distributed to students. Study documentation is done by collecting and studying the documents, information and supporting data. Data analysis techniques used in this research is a multiple linear regression model with linear equations.

$$
\mathbf{Y}=\mathbf{a}+\mathbf{b X 1}+\mathbf{b X 2}+\mathbf{e}
$$

Based on the results of the calculation of statistics using linear regression analysis to see the regression equation can be seen from table 1 below:

\section{Result}

The coefficient of determination (R2) is a rating that measures how far the proportion of a capability model in explaining the variation of free variables or the predictor. 
Determination of coefficient of test results on the research of model structure can be seen as follows:

Table 1.Test Results of Determination (R2) Regression Model

\begin{tabular}{|c|c|c|c|c|}
\hline \multicolumn{5}{|c|}{ Model Summaryb } \\
\hline $\begin{array}{c}\text { Mode } \\
1 \\
\end{array}$ & $\mathrm{R}$ & R Square & $\begin{array}{c}\text { Adjusted R } \\
\text { Square }\end{array}$ & $\begin{array}{l}\text { Std. Error of the } \\
\text { Estimate }\end{array}$ \\
\hline 1 & $\begin{array}{c}.914 \\
\mathrm{a}\end{array}$ & .836 & .833 & 1.93332 \\
\hline \multicolumn{5}{|c|}{ a. Predictors: (Constant), Motivation, Self-efficacy } \\
\hline \multicolumn{5}{|c|}{ b. Dependent Variable: Entrepreneurship_Interest } \\
\hline
\end{tabular}

Results from the table above that coefficients determinant (adjusted R) that are obtained of 0.833 . This means that $83.3 \%$ interest in entrepreneurship can be explained by motivation and self- efficacy while remaining $16.7 \%$ interest in entrepreneurship is explained by other variables not examined in this study.

F-Test (Test Simultaneous)

Table 2. Simultaneous Test Result (Test-F) Regression Model

\begin{tabular}{llllll}
\hline \multicolumn{7}{c}{ Model } & \multicolumn{1}{c}{$\begin{array}{c}\text { Sum of } \\
\text { Squares }\end{array}$} & \multicolumn{1}{c}{$\mathbf{d f}$} & $\begin{array}{c}\text { Mean } \\
\text { Square }\end{array}$ & F & Sig. \\
\hline Regression & 2469.870 & 2 & 1234.935 & 330.397 & $.000^{\text {a }}$ \\
\hline Residual & 485.904 & 130 & 3.738 & & \\
\hline Total & 2955.774 & 132 & & \\
\hline a.Predictors: (Constant), Motivation, Self_Confidence \\
\hline b. Dependent Variable: Entrepreneurship_Interest \\
\hline
\end{tabular}

Results from the above table it can be seen that $\mathrm{F}$ count of 330,397 with a significant level of 0.000 . While the $F$ tables at $95 \%$ confidence level with the $(\alpha=0.05)$ is 3,066 . Because $F$ value $>$ F tables $(330.397>3,066)$, Ho and Ha rejected accepted. This means there are confidence and motivation variables simultaneously effect significantly to entrepreneurship interest.

The T-Test, Test The Partially

Table 3. Partial Test results (test-t) Hypothesis

\begin{tabular}{cccccc}
\hline \multicolumn{7}{c}{ Coefficients $^{\mathbf{a}}$} \\
\hline \multicolumn{1}{c}{ Codel } & $\mathrm{B}$ & $\begin{array}{c}\text { Std. } \\
\text { Error }\end{array}$ & Beta & & \\
& & & & \\
\hline (Constant) & 4.5 & 1.629 & & 2.782 & .006 \\
& 30 & & .563 & 5.982 & .000 \\
\hline Self_efficac & .80 & .134 & & & \\
y & 1 & & .368 & 3.916 & .000 \\
\hline Motivation & .53 & .136 & & & \\
\hline
\end{tabular}

a. Dependent Variable: Entrepreneurship_Interest 
Results from table 3 above can be explained that the variables X 1 (efficacy) obtained $t$ count with a significant level of 5.9820 .000 . By using a limit of 0.05 significant then retrieved the $\mathrm{t}$ table 1.978. This means $\mathrm{t}$ value $>\mathrm{t}$ table, meaning Ho denied and $\mathrm{Ha}$ is received. Thus the first hypothesis is acceptable. And direction positive regression coefficients meaning selfefficacy effect against self-interest in entrepreneurship. This means that the higher the student's self-confidence also increased the interest in entrepreneurship students.

For the second hypothesis of the variable X 2 (motivation) obtained at $\mathrm{t}$ count with a significant level of 0.0009 .916 . By using a limit of 0.05 significant then retrieved the $t$ table 1.978. This means $t$ calculate $>\mathrm{t}$ table, meaning Ho denied and $\mathrm{Ha}$ is received. Thus the second hypothesis is acceptable. Positive regression coefficients and direction which emphasizes the positive motivation of influential on entrepreneurial intention. This means that the higher the motivation of University students to entrepreneurship the entrepreneurial intention also increased.

Based on the results of the output equation formula of regresinya is as follows:

$\mathrm{Y}=\beta_{0}+\beta_{1} \mathrm{x}_{1}+\beta_{2} \mathrm{x}_{2}+\mathrm{e}_{\mathrm{i}}$

$\mathrm{Y}=4.530+0,801 \mathrm{X}_{1}+0,553 \mathrm{X}_{2}+\mathrm{e}$

\subsection{The Influence of self-confidence On Entrepreneur-ship Interest}

From the results of testing the first hypothesis that can be obtained trust has a positive and significant effect on the interest in entrepreneurship. This can be explained by the theory according to (Sedarmayanti and Hidayat, 2011) that trust influences someone to make that choice. Anything that affects behavior is basically rooted in the belief to be able to achieve the expected target because basically, the existing entrepreneurial effort is to achieve a satisfying target. The results of this hypothesis are in line with the results of research by several previous researchers. According to (Supriyatno, 2017), which states that trust has a significant positive effect on the interest in entrepreneurship in STRI's PGRI Economics Education students and their pathways. Like (Setyowati, 2013) with the results of the study stating the influence of self-confidence in the interest in entrepreneurship of students at Vocational High School 10 Surabaya. And According to (Mcgee et al., 2009) and (Campo, 2011) state that the importance of including entrepreneurial self-efficacy (ESE) in the creation of new businesses, especially in business interests. Whereas according to (Asoni, 2012) states that self-confidence tends to create an interest in entrepreneurship. While the results of the research by (Trevelyan, 2008) state that self-confidence is very beneficial in developing creativity in starting a new business. From the results and opinions above can be concluded that self-confidence is needed in starting a business by creating interest in entrepreneurship.

\subsection{The Influence of Motivation on Entrepreneur-ship Interest}

From the results of the second hypothesis test can be obtained a positive and significant effect of motivation on the interest in entrepreneurship. This theory is reinforced by (Mahesa and Rahardja, 2012), the relationship of motivational factors is very close to interest. Motivational factors that influence the arising of someone's interest to take action or achieve goals. The results of this study are in line with previous research, namely (Saputri, Hari and Arief, 2016) that these variables have a positive effect on entrepreneurial motivation and interest in entrepreneurship significantly towards class XI of SMK Negeri 1 Kraksaan. According to Malebana (2014) states that motivation is intrinsic and extrinsic has a significant relationship to business interest. According to researchers (Santoso and OETOMO, 2018) and (Herdjiono et al., 2017) stated motivation is a stimulus in starting a new business. And (Marinič, Záthurecký and Špičák, 2015) also stated the prevalence of motivational factors to 
become entrepreneurs. According to (Das, 2016), motivation factors play a role in doing business. From the results of this study that motivation has a significant positive effect on students' interest in entrepreneurship at Polimedia. Entrepreneurial motivation encourages students to hone their creativity, especially in the IT business world.

\subsection{The Influence Of Self-Efficacy And Motivation On Entrepreneurship Interest}

From the results of testing the third hypothesis that is obtained simultaneously trust and motivation have a significant effect on the interest in entrepreneurship. This is in line with the results of (Supriyatno, 2017) research that shared trust and motivation have a significant positive influence on the interest in entrepreneurship. Meanwhile, according to (Santoso and OETOMO, 2018) states that motivation and self-confidence influence the interest in entrepreneurship. It was stated that high self-confidence and accompanied by high motivation also directly affect the level of interest of students in the Polymedia Field of entrepreneurship.

\section{Conclusions}

From the results presented above, it can be concluded:

1. Partially contained positive and significant influence on the variable trust themselves against interest student entrepreneurship Polimedia terrain. The results of the research showed when trust yourself in entrepreneurship then it will increase interest in entrepreneurship as well.

2. Partially contained positive and significant influence on the variables of motivation toward entrepreneurship students interest Polimedia terrain. The results of this study showed high motivation in students for entrepreneurship then it will improve interest in entrepreneurship.

3. Simultaneously, there is a significant influence on the variable self- belief and motivation towards entrepreneurship interest Polimedia terrain. The results of this research indicate high confidence and a strong motivation will increase student interest in entrepreneurship.

\section{Suggestions}

1. Student Polimedia Field expected to learn and understand more courses in entrepreneurship and the Medan Polimedia trying to improve the quality of students in all aspects of good entrepreneurship so that confidence High student so the student interest is on the rise.

2. the parties are expected to pay more attention to Terrain Polimedia motivation of college students in the entrepreneurship either extrinsic or intrinsic motivation to help students to improve her interest in entrepreneurship.

3. the parties are expected to Field capable of Polimedia in collaboration with students in order to make the process of learning especially to entrepreneurship reached so as to create a sense of self-efficacy accompanied with a strong motivation to increase the interest students in entrepreneurship.

\section{Acknowledgements}

The authors thank all parties involved in this research and to the Creative Multimedia Polytechnic Medan that invitation was to provide information and support for this research 


\section{References}

[1] Adhitama, P. P. (2014) 'Faktor-Faktor Yang Mempengaruhi ( Studi Kasus Mahasiswa Fakultas Ekonomika Dan Bisnis Undip , Semarang )', Universitas Diponegoro, pp. 13-27. doi: 10.1080/10293574.1999.10510566.

[2] Agustina, C. and Sularto, L. (2011) 'Intensi Kewirausahaan mahasiswa', in PESAT (Psikologi Ekonomi Sastra Arsitektur \& Sipil). Depok, pp. 63-69. Available at: http://publication.gunadarma.ac.id.

[3] Asoni, A. (2012) 'Intelligence, Self-Confidence and Entrepreneurship', Ssrn, (887). doi: 10.2139/ssrn.2050371.

[4] Bandura, A. (1994) Self Efficacy. New York: Academic Press.

[5] Basrowi (2014) Pengantar Sosiologi. Bogor: Ghalia Indonesia.

[6] Baum, J. R., FRESE, M. and Baron, R, A. (2007) The Psychology of Entrepreneurship. Mhawa, New Jersey: Lawrences Erlbaum Associates.

[7] Buchari, Z. (2007) Manajemen dan Motivasi. Revition. Jakarta: Balai Aksara.

[8] Budiati, Y., Yani, T. E. and Universari, N. (2012) 'Minat Mahasiswa Menjadi Wirausaha ( Studi Pada Mahasiswa Fakultas Ekonomi Universitas Semarang )', J. Dinamika Sosbud, 14, pp. 89-100. Available at: file://C:/Users/user/Downloads/Documents/MINAT_MAHASISWA_MENJADI_W IRAUSAHA_STUDI.pdf.

[9] Campo, J. L. M. (2011) 'Analysis of the influence of self-efficacy on entrepreneurial intentions, Prospect, 9(2), pp. 14-21. Available at: http://dialnet.unirioja.es/descarga/articulo/4208261.pdf.

[10] Chen,Chao,C., \& A. C. (1998) 'Does Entrepreneurial self-efficacy distinguish entrepreneurs from managers', Journal of Business Venturing, 13(4), pp. 295-316. doi: https://doi.org/10.1016/S0883-9026(97)00029-3.

[11] Das, D. C. (2016) ““ Influences of Motivational Factors on Entrepreneurship : A study of Rangia Development Block under Rangia Sub- Division in Kamrup District , Assam ",, 5264(38), pp. 38-44.

[12] Franco, Mario., Heiko Haase., \& Arndt Launtenschlager, A. (2010) "'Students", Entrepreneurial Intentions: An Inter-Regional Comparison"'”, Education + Training, 52(4), pp. 260-275. doi: https://doi.org/10.1108/00400911011050945.

[13] Ghufron, M, N. and Risnawita, R. (2010) Teori-Teori Psikologi. Yogyakarta: ArRuzz Media.

[14] Herdjiono, I. et al. (2017) 'The Factors Affecting Entrepreneurship Intention', International Journal of Entrepreneurial Knowledge, 5(2), pp. 5-15. doi: 10.1515/ijek-2017-0007.

[15] Hrehová, D. (2013) 'Motivation to become an entrepreneur', 0638, pp. 42-46.

[16] Kuratko, Donald ,F.,Hornsby, Jeffry,S., \& Naffziger, D. W. (1997) 'An Examination of Owners' Goals in Sustaining Entrepreneurship', Journal of Small Business Management, 35(1), pp. 24-33.

[17] Mahesa, A. D. and Rahardja, E. (2012) 'Analisis Faktor-Faktor Motivasi Yang', 1, pp. 1-8. doi: 1.1371/journal.pmed.1316.

[18] Marinič, P., Záthurecký, V. and Špičák, O. (2015) 'Motivation of University Students as Future Entrepreneurs', Central European Journal of Management, 1(2), pp. 51-69. doi: 10.5817/CEJM2014-2-4.

[19] Mcgee, J. E. et al. (2009) 'Entrepreneurial self-efficacy: Refining the measure', Entrepreneurship: Theory and Practice, 33(4), pp. 965-988. doi: 10.1111/j.1540- 
6520.2009.00304.x.

[20] Robicahud, Y., Mcgraw, E. and Roger, A. (2001) 'Towards the Development of a Measuring Instrument for Entrepreneurial Motivations', Journal of Developmental Entrepreneurship, 6(2), pp. 189-201.

[21] Ryan, T. . (1970) Intentional Behavior: An Approach to Human Motivation. New York: The Ronald Press Company.

[22] Santoso, S. and OETOMO, B. S. D. (2018) 'Influence of Motivation and SelfEfficacy on Entrepreneurial Intention to Run a Business', Expert Journal of Marketing, 6(1), pp. 14-21. Available at: http://marketing.expertjournals.com/23446773-603/.

[23] Saputri, H., Hari, M. and Arief, M. (2016) 'Pengaruh Motivasi Berwirausaha Terhadap Minat Berwirausaha Melalui Prestasi Belajar Mata Pelajaran Kewirausahaan Siswa Kelas XI SMK Negeri 1 Kraksaan', Jurnal Pendidikan Bisnis dan Manajemen, 2(2), pp. 123-132.

[24] Sarosa, P. (2005) 'Kiat Praktis Membuka Usaha. Becoming young entrepreneur: dream big start small, act now! panduan praktis \& motivasional bagi kaum muda dan mahasiswa', in. Jakarta: PT. Elexmedia Komputindo.

[25] Schumpeters, J. A. (1965) Economic Theory and Entrepreneurial History In: Aitken $H G(e d)$ Explorations in Entreprise. Cambridge: Havar University Press.

[26] Sedarmayanti, H. and Hidayat, S. (2011) Metodologi Penelitian. Bandung: Mandar Maju.

[27] Segal, G., Borgia, D. and Schoenfield, J. (2005) 'The motivation to become an entrepreneur', International Journal of Entrepreneurial Behaviour and Research, 11(1), pp. 42-57. doi: 10.1108/13552550510580834.

[28] Setyowati, D. I. (2013) 'PENGARUH PEKERJAAN ORANG TUA DAN KEYAKINAN DIRI TERHADAP MINAT BERWIRAUSAHA SISWA DI SMK NEGERI 10 SURABAYA Dwi Indah Setyowati *', Jurnal Ekonomi Pendidikan dan Kewirausahaan, 1(2), pp. 121-129.

[29] Sudardjo, S. and Purnamaningsih, E. H. (2003) 'Kepercayaan diri dan kecamasan komunikasi interpersonal pada mahasiswa', Jurnal Psikologi, 30(2), pp. 67-71. doi: 10.22146/jpsi.7025.

[30] Sugiyono (2015) Metodologi Penelitian Kuantitatif, Kualitatif dan R\&D. Bandung: Alfabeta.

[31] Sumarwan, U. (2003) Perilaku Konsumen. Jakarta: Ghalia Indonesia.

[32] Supriyatno, B. (2017) 'Pengaruh Kepercayaan Diri dan Motivasi terhadap Minat Berwirausaha Mahasiswa Program Studi Pendidikan Ekonomi STKIP PGRI Ngawi’, Jurnal Media Prestasi, XVII(1), pp. 48-61. doi: http://dx.doi.org/10.4135/9781412961288.n337.

[33] Suryana, Y. and Bayu, K. (2013) Kewirausahaan Pendekatan Karakteristik Wirausaha Sukses. 2nd edn. Jakarta: Kencana Pranada Media Group.

[34] Trevelyan, R. (2008) 'Optimism, overconfidence and entrepreneurial activity', Management Decision, 46(7), pp. 986-1001. doi: 10.1108/00251740810890177.

[35] Venesaar, U., Kolbre, E. and Piliste, T. (2006) 'Students' Attitudes and Intentions toward Entrepreneurship at Tallinn University of Technology', Tutwpe, (154), pp. 97-114. 
